\title{
Natural photoprotectors: A literature review
}

\author{
Fotoprotetores naturais: Uma revisão de literatura \\ Fotoprotectores naturales: Una revisión de la literatura
}

Received: 04/02/2021 | Reviewed: 04/11/2021 | Accept: 04/13/2021 | Published: 04/25/2021

Rejanne Lima Arruda
ORCID: https://orcid.org/0000-0001-7173-2645
Universidade Federal de Goiás, Brazil
E-mail: rejanne.lima.arruda@ hotmail.com
Nathália Olívia de Sousa Garcia
ORCID: https://orcid.org/0000-0002-8471-2587
Universidade Federal de Goiás, Brazil
E-mail: nathalia.sousagarcia @ gmail.com
Nathália Ferreira Souza
ORCID: https://orcid.org/0000-0001-6690-2320
Universidade Federal de Goiás, Brazil
E-mail: nathaliasouza.riot@gmail.com
Fernanda Maria da Silva
ORCID: https://orcid.org/0000-0001-9638-1669
Universidade Federal de Goiás, Brazil
E-mail: nandamariadasilva@ hotmail.com
Evilanna Lima Arruda
ORCID: https://orcid.org/0000-0002-8861-7210
Universidade Federal de Goiás, Brazil
E-mail:evilannalima @gmail.com
Edemilson Cardoso da Conceição
ORCID: https://orcid.org/0000-0003-4113-2686
Universidade Federal de Goiás, Brazil
E-mail:ecardosoufg@ gmail.com

\begin{abstract}
Ultraviolet (UV) radiation has contributed to the onset of various skin diseases, including skin cancer. Consequently, there are a series of incentives for research and development of innovative photoprotectors that can provide protection against such health problems. With the growing consumer interest in cosmetic products of natural origin, there has been an increase in new proposals such as the replacement of synthetic assets with molecules extracted from medicinal plants that present activity compatible or superior to synthetic products and with lesser environmental impact. Natural photoprotectors are gaining attention within this scenario, and some previous studies have demonstrated their potential for use. A literature review was conducted on the main groups and active principles of plants with photoprotective activity and for this purpose we used national and international scientific articles from the Medline/PubMed, SCIELO, LILACs, Science Direct, Scopus and Google Scholar databases. We mentioned 17 different species of medicinal plants with photoprotective action and their respective active ingredients. The flavonoid group was the most cited and studied in relation to the protective capacity against ultraviolet radiation and its isolated action and synergistic action was highlighted. Studies show that plant extracts from different plant species have a photoprotective action, among which they highlight the rich in antioxidant compounds, such as plants of the species Ginkgo biloba, Psidium guajava, Camellia sinensis and Lippia sp. which stand out for their large amount of polyphenols, especially flavonoids.
\end{abstract}

Keywords: Ultraviolet radiation; Skin aging; Sun protection.

\section{Resumo}

A radiação ultravioleta (UV) tem contribuído para o surgimento de várias doenças de pele, incluindo o câncer de pele. Consequentemente, há uma série de incentivos para a pesquisa e desenvolvimento de fotoprotetores inovadores que possam fornecer proteção contra tais problemas de saúde. Com o crescente interesse dos consumidores por produtos cosméticos de origem natural, houve um aumento de novas propostas, como a substituição de ativos sintéticos por moléculas extraídas de plantas medicinais que apresentam atividade compatível ou superior a produtos sintéticos e com menor impacto ambiental. Fotoprotetores naturais estão ganhando atenção dentro desse cenário, e alguns estudos anteriores demonstraram seu potencial de uso. Foi realizada uma revisão de literatura sobre os principais grupos e princípios ativos de plantas com atividade fotoprotetora e para isso utilizou-se artigos científicos nacionais e internacionais das bases de dados Medline/PubMed, SCIELO, LILACs, Science Direct, Scopus e Google Scholar. Foram citados 17 espécies diferentes de plantas medicinais com ação fotoprotetora e seus respectivos princípios 
ativos. O grupo dos flavonoides foi o mais citado e estudado em relação a sua capacidade de proteção contra radiações ultravioleta e foi destacado tanto sua ação isolada como sua ação sinérgica. Estudos comprovam que extratos vegetais de diferentes espécies de plantas apresentam ação fotoprotetora, dentre estes destacam os ricos em compostos antioxidantes, como por exemplo plantas da espécie Ginkgo biloba, Psidium guajava, Camellia sinensis e Lippia sp. as quais destacam-se por sua grande quantidade de polifenois, em especial dos flavonoides.

Palavras-chave: Radiação ultravioleta; Envelhecimento da pele; Proteção solar.

\section{Resumen}

La radiación ultravioleta (UV) ha contribuido a la aparición de varias enfermedades de la piel, incluido el cáncer de piel. En consecuencia, existen una serie de incentivos para la investigación y el desarrollo de fotoprotectores innovadores que pueden proporcionar protección contra tales problemas de salud. Con el creciente interés de los consumidores por los productos cosméticos de origen natural, se ha producido un aumento de nuevas propuestas, como la sustitución de activos sintéticos por moléculas extraídas de plantas medicinales que tienen actividad compatible o superior a los productos sintéticos y con menor impacto ambiental. Los fotoprotectores naturales están ganando atención dentro de este escenario, y algunos estudios previos han demostrado su potencial de uso. Se llevó a cabo una revisión de la literatura sobre los principales grupos y principios activos de las plantas con actividad fotoprotectora y para ello utilizamos artículos científicos nacionales e internacionales de las bases de datos Medline/PubMed, SCIELO, LILACs, Science Direct, Scopus y Google Scholar. Mencionamos 17 especies diferentes de plantas medicinales con acción fotoprotectora y sus respectivos ingredientes activos. El grupo flavonoide fue el más citado y estudiado en relación con la capacidad protectora contra la radiación ultravioleta y se destacó su acción aislada y su acción sinérgica. Los estudios demuestran que los extractos de plantas de diferentes especies vegetales tienen acción fotoprotectora, entre las que destacan las ricas en compuestos antioxidantes, como plantas de las especies Ginkgo biloba, Psidium guajava, Camellia sinensis y Lippia sp. que destacan por su gran cantidad de polifenoles, especialmente flavonoides.

Palabras clave: Radiación ultravioleta; Envejecimiento de la piel; Protección solar.

\section{Introduction}

Over the years, there has been a considerable reduction in the ozone layer, resulting in an increase in the intensity of ultraviolet (UV) radiation on the Earth's surface. Consequently, the harm caused by this high exposure has led to a greater need for protection of the human skin to reduce health impacts such as the development of erythema, hyperpigmentation, and even skin cancer (Saewan \& Jimtaisong, 2015; Barnes et al., 2019). There are different ways to protect the skin against the harmful effects of UV radiation, but the most commonly used method is the application of sunscreen products that absorb or reflect UV radiation. Most photoprotective products have compounds of synthetic origin, either organic or inorganic; however, the pharmaceutical and cosmetic industries have been perceiving an increase in the demand for more natural formulations to make the products more sustainable, less aggressive to the skin, and offer the same efficiency as synthetic products.

The application of extracts and oils from medicinal plants in cosmetic products, such as sunscreens, has been growing because of the photoprotective action detected in several plant species and their wide range of biological action. Secondary metabolites with chemical structures similar to those of synthetic chemical filters have greater photoprotective potential. The absorption spectrum of active ingredients of natural origin is not well defined because it is a complete mixture that contains a large variety of active molecules, resulting in a broad spectrum of UV absorption. Their application can include both the replacement of chemical filters and enhancers of sun protection factor (SPF) (Rancan et al., 2002; Ferrari et al., 2008; Singh \& Kumar, 2018). In view of the importance of developing new sunscreens based on natural products, this study aims to describe the main secondary metabolites with photoprotective action already described in literature.

\section{Methodology}

A narrative review was carried out (Pereira et al., 2018), through bibliographic research on the active principles of plant species with photoprotective action. National and international scientific articles from medline/pubmed, SCIELO, LILACs, Science Direct, Scopus and Google Scholar databases were used. 


\section{Results and Discussion}

\subsection{Effect of solar radiation on the skin}

Sunlight is composed of a continuous spectrum of electromagnetic radiation that presents division and denomination in agreement with the wavelength range $(\lambda)$ : UVC $(100-280 \mathrm{~nm}), \mathrm{UVB}(280-320 \mathrm{~nm})$, and UVA (320-400 nm) (Epstein, 1990; Flor et al., 2007; Guaratini et al., 2009). The UVC region is absorbed by the ozone layer is known to be a germicidal or bactericidal region. Upon reaching unprotected skin, the cumulative action of UVC radiation and high energy associated with the wavelength induce a complex process, which is associated with chemical and morphological reactions, that is highly harmful to humans, showing carcinogenic and mutagenic effects (Araújo \& Souza, 2008). Although UVB radiation has a short wavelength and less power to penetrate the skin, it is the most energetic form of UV radiation and therefore leads to erythema, hyperpigmentation, DNA damage, inflammation, and especially carcinogenesis. UVA radiation has greater penetrating power, leading to skin hyperpigmentation, cancer induction, premature aging, and photosensitivity (Simis \& Simis, 2006; Balogh et al., 2011).

The intensity of radiation and wavelength of sunlight depend on factors such as altitude, latitude, season, weather, and time. However, in general, the most harmful radiation occurs between 10-11 am and 16-17 pm (Toffetti \& De Oliveira, 2006). Excessive exposure to solar radiation increases the risk of skin cancer (Chiari-Andréo et al., 2020). Therefore, awareness of skin cancer and other negative health effects, as well as preventive measures, has become a public health issue.

Exposure to UV radiation in the appropriate amount and for a short period can have benefits, including production of vitamin D3 (Sampaio \& Rivitti, 2001), maintenance of skin tanning for cosmetic purposes, improvement in mood, treatment of skin conditions with phototherapy, treatment of atopic dermatitis, and pain relief (Juzeniene \& Moan, 2012).

\subsection{Photoprotection}

Sunscreens emerged when it was discovered that certain substances are capable of preventing damage caused by sunlight. They are cosmetic preparations for topical use capable of reducing the intensity of UV radiation reaching the human skin through two mechanisms of action: absorption and/or reflection (Perugini et al., 2002).

In 1928, the United States commercialized its first sunscreen. However, the Food and Drug Administration classified the UV filters that were authorized to compose photoprotective formulations in 1978 (Toffetti \& De Oliveira, 2006). Sunscreens are cosmetics composed of photoprotective active ingredients and a base formulation that is characterized as a vehicle. This base formulation can be composed of emollients, rheology modifiers, humectants, moisturizers, preservatives, emulsifiers, gelling agents, and other components that characterize the shape of the vehicle-from simple gels to more complex structures such as emulsions and the final skin feel (Flor et al., 2007).

The photoprotective effectiveness of sunscreens depends on factors such as the absorption interval, wavelength at which the maximum absorption occurs, and their ability to absorb radiant energy, which is proportional to their concentration (Johncock, 2000). Along with these factors, the perceived effectiveness of a sunscreen is evaluated by its ability to protect the skin from erythema and edema and reduce the risk of burns and carcinoma development (Toyoshima et al., 2004). One of the ways to increase the photoprotective effectiveness of formulations is through the association of different filters of the same class or different classes to offer a greater range of protection (Araújo \& Souza, 2008; De Paola \& Ribeiro, 1998).

There are two classes of sunscreens, namely organic and inorganic, which are classified as chemical effect filters (chemical UV filters) and physical effect filters (physical UV filters), respectively (Flor et al., 2007). Chemical or organic filters are generally aromatic compounds with a carbonyl group (or part of a ketone or an ester) and an electron-releasing substitute (usually an amine or methoxy group) in the ortho or para position of the benzene ring (Violante et al., 2009). 
Physical or inorganic filters are generally of mineral origin. They are opaque substances that, when applied to the skin, reflect and disperse light energy and form a physical barrier to UVA/UVB, infrared (IR), and visible radiations, resulting in the formation of a protective film on the skin (Flor et al., 2007; Toffetti \& De Oliveira, 2006; Ribeiro, 2006).

In general, organic compounds protect the skin by absorbing radiation, whereas inorganic compounds protect the skin by reflecting radiation. There are currently organic filters in the market that reflect UV radiation besides absorbing UV. Among the physical filters applied in sunscreens, the most commonly used are titanium dioxide, zinc oxide, magnesium oxide, kaolin, and iron oxide (Flor et al., 2007; Toffetti \& De Oliveira, 2006; Violante et al., 2009; Ribeiro, 2006). According to Jallad and Karim (2016), among organic filters, there are those with UVB absorption capacity, such as derivatives of paraaminobenzoates, salicylates, cinnamates, and camphor, and those with UVA absorption capacity such as benzoenes, antranilates, and dibenzometans.

Despite the effectiveness of synthetic chemical filters, studies have demonstrated their side effects in humans and damage to the environment. The awareness of this information has led to a worldwide trend toward the use of natural ingredients to replace synthetic chemical filters in photoprotective formulations (Korkina et al., 2018).

\subsection{Secondary metabolites with photoprotective action}

The use of plant-based assets in cosmetic formulations has increased over the years owing to the search for new sustainable sources of raw materials, greater concerns on safety related to synthetic products, and possible environmental impacts caused by the incorrect disposal of these products (Mota et al., 2020). Skarupova et al. (2020) reported some promising plants for use against solar radiation and the secondary metabolites responsible for the photoprotective action (Table $1)$.

Table 1. Plant species and respective secondary metabolites with photoprotective potential.

\begin{tabular}{|c|c|c|}
\hline Species & Family & Main secondary metabolites \\
\hline Camellia sinensis & Theaceae & $\begin{array}{l}\text { (-)-epicatechin }(E C), \quad(-) \text {-epicatechin-3-gallate (ECG), (-)- } \\
\text { epigallocatechin (EGC), and (-)-epigallocatechin-3-gallate (EGCG) }\end{array}$ \\
\hline Silybum marianum & Compostae & Flavonolignans silibina \\
\hline Punica granatum & Lythraceae & $\begin{array}{l}\text { phenolic acids, flavanols, flavones, flavonones, anthocyanidins, and } \\
\text { anthocyanin }\end{array}$ \\
\hline Polypodium leucotomos & Polypodiaceae & Chlorogenic, p-coumaric, vanillic, cinnamic, caffeic, and ferulic acid \\
\hline Vaccinium myrtillus & Ericaceae & flavonoids, anthocyanins \\
\hline Lonicera caerulea & Caprifoliaceae & anthocyanins, flavonoids, and phenolic acids \\
\hline Thymus vulgaris & Lamiaceae & $\begin{array}{l}\text { Terpenes: thymol (2-isopropyl-5-methylphenol), carvacrol, and } \\
\text { borneol }\end{array}$ \\
\hline Opuntia effec-indica & Cactaceae & $\begin{array}{l}\text { Vitamins, phenolic acids, and flavonoids, especially quercetin 3- } \\
\text { methyl ether }\end{array}$ \\
\hline
\end{tabular}




\begin{tabular}{|c|c|c|}
\hline Morinda citrifolia & Rubiaceae & $\begin{array}{l}\text { terpenoids, alkaloids, anthraquinones, flavonoids and their } \\
\text { glycosides }\end{array}$ \\
\hline Aloe vera & Liliaceae & $\begin{array}{l}\text { phenolic compounds, anthracene hydroxyl derivatives [namely aloin } \\
\text { A and B (collectively known as barbaloin), emodin, anthranol] }\end{array}$ \\
\hline Oenothera paradoxa & Oenotheraceae & polyphenolic compounds (flavonoids, phenolic acids, and e tannins) \\
\hline Galinsoga parviflora & Asteraceae & $\begin{array}{l}\text { flavonoids and their glycosides [patulitrin (patuletin-7-O- } \beta \text {-D- } \\
\text { glucoside), quercimeritrin (quercetin7-O- } \beta \text {-D-glucoside] }\end{array}$ \\
\hline Galinsoga quadriradiata & Asteraceae & $\begin{array}{l}\text { flavonoids and their glycosides [patulitrin (patuletin-7-O- } \beta \text {-D- } \\
\text { glucoside)] }\end{array}$ \\
\hline Hippophae rhamnoides & Elaeagnaceae & $\begin{array}{l}\text { vitamins ( } \mathrm{C}, \mathrm{E} \text { and } \mathrm{K}) \text {, polyphenols, carotenoids, sterols, minerals, } \\
\text { amino acids, saturated and unsaturated fatty acids }\end{array}$ \\
\hline Cola acuminata & Malvaceae & $\begin{array}{l}\text { caffeine, theobromine, and polyphenols, including D-catechin, L- } \\
\text { epicatechin, procyanidin B1 and B2, and tannins }\end{array}$ \\
\hline Theobroma cacao & Malvaceae & $\begin{array}{l}\text { flavonoids, catechins, epicatechins, procyanidins and xanthine } \\
\text { derivatives (caffeine and theobromine) }\end{array}$ \\
\hline Amaranthus cruentus & Amaranthaceae & $\begin{array}{l}\text { flavonoids, phenolic acids, essential amino acids, bioactive peptides, } \\
\text { micro- and macronutrients, including minerals and vitamins }\end{array}$ \\
\hline
\end{tabular}

Source: Skarupova et al. (2020).

Among the plant species mentioned in Table 1, Camellia sinensis stands out, a plant of the Theaceae family that has many important properties for health. Regarding the photoprotective activity, the most studied metabolites with this action are: (-)-epicatechin (EC), (-)-epicatechin-3-gallate (ECG), (-)-epigallocatechin (EGC), and (-)-epigallocatechin-3-gallate (EGCG). In the species Aloe vera (Liliaceae), the metabolites studied with protective power against UV radiation were: phenolic compounds, anthracene hydroxyl derivatives [namely aloin A and B (collectively known as barbaloin), emodin, anthranol].

Table 1 shows that the main metabolites belong to the group of polyphenols.Polyphenols have a molecular structure comprising condensed aromatic rings of 5-6 carbons with several hydroxyl groups (OH) that are capable of effectively absorbing UV radiation covering the UVA and UVB spectra. Moyal and Fourtanier (2008) stated that photoprotective formulations containing plant extracts rich in polyphenols are more effective and safer than those containing synthetic filters, because they have structurally aromatic rings; however, compounds from plants have reduced toxicity. Among the polyphenols known for their photoprotective activity, verbascoside phenylpropanoids and quercetin flavonoids have been highlighted (Busbee et al., 2013).

In addition to flavonoids, anthocyanins and cinnamic acid derivatives have the ability to absorb UV radiation (RAMOS et al., 2010). Other secondary metabolite classes containing non-aromatic chromophore groups have also been highlighted, such as tocotrienols, carotenoids, and mycosporins (Guaratini et al., 2009).

Lívia et al. (2018) demonstrated the synergistic capacity of Psidium guajava extract added to a sunscreen containing the chemical filter ethylhexyl methoxycinate, which had a $17.99 \%$ increase in SPF. The authors attribute the increase in SPF to 
the presence of phenols and flavonoids in the extract added to the formulation. Seok et al. (2016) also found an increase in SPF of a sunscreen with synthetic filters after the insertion of Scutellaria baicalensis butanolic extract.

Polonini et al. (2014) studied the photoprotective action of four species of Lippia and found that the extract of Lippia. sericea showed the best photoprotective action in vitro and in vivo, highlighting that it is the species that presented the greatest amount of total phenols. Wolf et al. (2001) stated that to achieve an ideal composition of sunscreens with high UVA and UVB protection, it is necessary to associate several molecules containing polyphenols, such as those derived from cinnamic or benzoic acid.

\subsection{Flavonoids with photoprotection activity}

The structure of flavonoids is composed of a nucleus consisting of three phenolic rings, two benzene rings (A and B), which are connected through a heterocyclic pyran or pyrone (with a double bond), and a $\mathrm{C}$ ring in the center (Tapas et al., 2008), as shown in Figure 1. The subclasses of flavonoids are based mainly on the presence (or absence) of a double bond at position 4 of the $\mathrm{C}$ ring (intermediate), presence (or absence) of a double bond between the atoms carbon 2 and 3 of ring $\mathrm{C}$, and presence of hydroxyl groups in ring B (Saewan \& Jimtaisong, 2013). Among the subclasses of flavonoids, the main ones are flavones, flavonols, flavanois, isoflavones, and anthocyanins (Bhagwat et al., 2011).

Figure 1. Chemical structure of flavonoids.

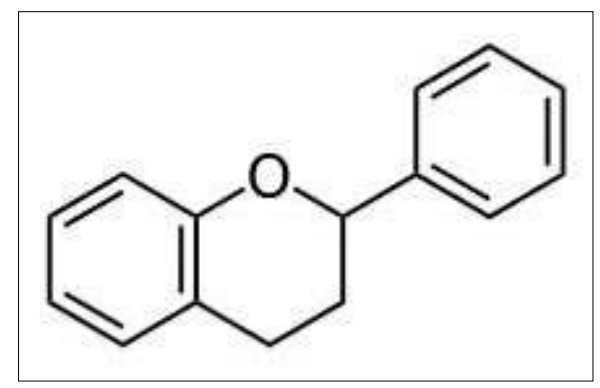

Source: Search data.

Flavonoids have three photoprotective mechanisms of action, namely absorption of UV radiation, direct and indirect antioxidants, and ability to modulate different effecting pathways (Bosch et al., 2015). The absorption of radiation by flavonoids occurs at two different absorption peaks, at wavelengths between 240-280 nm and 300-550 nm, while the commercially used broad-spectrum UV filters absorb radiation between 290-320 nm (UVB) and 320-400 nm (UVA), which guarantees its efficiency in sunscreen formulations (Bobin et al., 1995).

Studies have shown that herbal extracts from different plant species have a photoprotective action, such as Ginkgo biloba, P. guajava, Camellia sinensis, and Lippia sp. species that are known for their large amounts of polyphenols, especially flavonoids, and antioxidant activity.

\subsubsection{Flavones}

Flavones are natural chemical protectors that absorb light at shorter wavelengths than those visible to the human eye, thus protecting plant cells from damage caused by photooxidation (Bosch et al., 2015). They have two main absorption peaks, the $290-400 \mathrm{~nm}$ peak contributed by the cinamoil part of the molecule and 240-285 nm peak contributed by the benzol part (Jiang et al., 2016).

The main flavones found in nature are apigenin and chrysin (Bosch et al., 2015). Filho et al. (2016) reported that owing to the high antioxidant potential of apigenin, a formulation based on this compound can confer a broad spectrum of 
protection in the UVA and UVB regions. They stated that topically applied apigenin-based formulations reduce tumor activity via inhibiting the enzyme ornithine decarboxylase by decreasing UV radiation absorption.

Birt et al. (1997) showed the protective effects of apigenin in preventing cutaneous carcinogenesis induced by UVA and UVB in mice. Van Dross et al. (2007) reported that UVB-induced Cox 2 protein in keratinocytes is blocked after treatment with apigenin.

Silva et al. (2014) used three glycosylated flavones (1) 2' = O - ramnosylvitexin, (2) 4', 5,7-trimethoxy-2'=-Oramnosylvitexin, and (3) ligustroflavone extracted from Alternanthera brasiliana extract (L) Kuntze and proved the in vitro photoprotective action of these glycosylated flavones. The SPF results were dependent on the concentration studied.

\subsubsection{Flavanols}

Flavonoids are compounds found in medicinal plants and fruits, and they are present in high quantities in green vegetables. Quercetin, canferol, mircetin, and rutin are the main flavonoids found in nature, with quercetin being the compound with the greatest antioxidant activity (Survay et al., 2011). Quercetin is present in fruits and vegetables, such as apples, lemons, tomatoes, onions, and lettuce, in addition to herbs, drinks, olive oil, and bee propolis (Inal et al., 2001).

In studies of formulations containing only quercetin (3,3', 4', 5,7-pentahydroxyflavone) as an active ingredient in association with other filters, by using the transmittance method proposed by Diffey and Robson (1989), it was observed that quercetin has absorption in the UVA and UVB regions. The authors stated that the formulations remained stable after $2 \mathrm{~h}$ of controlled irradiation. They also noticed an increase in the protective action when the same compound was associated with the physical filters titanium dioxide and zinc oxide, thus showing a synergistic effect (Diffey \& Robson, 1989).

Choquenet et al. (2008) evaluated the photoprotective properties of quercetin in combination with its glycoside rutin (quercetin-3-O-rutinoside), and the results showed that the formulation had a 10\% SPF greater than the control.

\subsubsection{Flavanois}

Flavanois are commonly known as catechins, which are isomers with a trans configuration, and epicatechin, which is classified as an isomer with a cis configuration. Each of these configurations has two stereoisomers; thus, we have catechin (-), catechin (+), epicatechin (-), and epicatechin (+). The largest source of catechins in the human diet is through green tea (Tsao et al., 2003).

Catechins are powerful antioxidants that inhibit reactive oxygen species-induced DNA damage, immunosuppression, and UV radiation-induced skin inflammation (Guaratini et al., 2007). Regarding the photoprotective activity of this group of flavonoids, Camouse et al. (2009) demonstrated that the topical application of green tea and white tea extracts, both with a high concentration of catechins, before exposure to UV radiation significantly reduced the oxidative damage to keratinocyte DNA.

\subsubsection{Isoflavones}

Isoflavones are representative of plant phytoestrogens, which show an effect similar to that of estrogen present in humans. They are found more frequently in legumes, including soybeans, black beans, green beans, and chickpeas (Saewan \& Jimtaisong, 2013).

Genistein is one of the most well-known compounds in this class and has a photoprotective action. A study performed on the skin of rats found activity against UVB radiation, demonstrating the regulation of oxidative stress, photodamage, and UVB-induced carcinogenesis (Wei et al., 2002). Lin et al. (2008) reported that the action of genistein is due to its ability to inhibit the activity of tyrosine kinase receptor, leading to a reduction in the damage caused by UV radiation. Wei et al. (2002) 
reported that genistein can effectively block skin burns induced by UVB radiation in humans, such as psoralen, followed by UVA-induced photodamage.

Other isoflavones, such as equol and estrogen metabolized from daidzein, reduced the incidence of cancer caused by chronic exposure to UV radiation and UVA-induced lipid peroxidation in mouse skin (Widyarini et al., 2005). Another study showed that the application of topical solutions containing $0.5 \%$ genistein, daidzein, biochanin A, and formononetin exerted photoprotective effects on the skin of pigs, thus reducing the number of sunburn cells formed by UV radiation (Lambert et al., 2007).

\subsection{Anthocyanins}

Anthocyanins are vegetable pigments responsible for a wide variety of colors found in fruits, vegetables, cereal grains, and flowers (Yoshida et al., 2006). They have effective antioxidant properties and act to combat photooxidative stress (Gould, 2004). According to Bordignon et al. (2009), anthocyanins have antioxidant properties and absorb radiation in the $400-600 \mathrm{~nm}$ range, demonstrating their photoprotective activity.

Giampieri et al. (2012) demonstrated an increase in cell viability and decrease in UVA-induced DNA damage in human dermal fibroblasts following treatment with strawberry extract (rich in the anthocyanin called perlagonidine). They stated that this activity is due to the ability of anthocyanins to block the destruction of collagen and inflammatory responses via NF- $\kappa$ B and MAPK signaling transcription mechanisms.

\section{Conclusion}

Based on the findings of the studies described here, it can be said that the herbal kingdom represents the main conventional source of new candidates with photoprotective activity. As documented, there is a range of secondary metabolites that have UVA and UVB protection properties; therefore, they can be useful in protecting and treating damage caused by these radiations, either alone or in combination with traditional UV filters. Studies show that plant extracts from different plant species have a photoprotective action, among which they highlight the rich in antioxidant compounds, such as plants of the species Ginkgo biloba, Psidium guajava, Camellia sinensis and Lippia sp. which stand out for their large amount of polyphenols, especially flavonoids.

The vast majority of studies were carried out in in vitro systems owing to the prohibition on the use of animals for these tests. However, the results hold great importance in promoting new studies and more effective and beneficial formulations to the environment and humans. New studies must be carried out in order to verify the stability of the newly elaborated phytocosmetics, as well as the possible adverse reactions of the use of these products.

\section{Acknowledgments}

To the Bioproduct Research, Development and Innovation Laboratory.

\section{References}

Araújo, T. S., \& Souza, S. O. de (2008). Protetores solares e os efeitos da radiação ultravioleta. Revista Scientia Plena 4(1):1-7.

Balogh, T. S, Velasco, M. V. R, Pedriali. C. A., Kaneko, T. A., \& Baby, A. R. (2011). Proteção à radiação ultravioleta: recursos disponíveis na atualidade em fotoproteção. Brazilian Annals of Dermatology 86(4):732-742.

Barnes, P. W., Williamson, C. E., Lucas, R. M., Robinson, S. A. \& Madronich, S. (2019). Ozone depletion, ultraviolet radiation, climate change and prospects for a sustainable future. Nature Sustainability 2:569-579. 
Bhagwat, S., Hayytowitz, D. B \& Holden, J. M (2011). USDA Database for the Flavonoid Content of Selected Foods. U.S. Department of Agriculture: Agricultural Research Center, Release 3, pp. 10-12.

Birt, D. F., Mitchell, D., Gold, B., Pour, P. \& Pinch, H. C. (1997). Inhibition of ultraviolet light induced skin carcinogenesis in SKH-1 mice by apigenin, a plant flavonoid. Anticancer Research 17(1A): 85-92.

Bobin, M. F., Raymond, M., \& Martini, M. C. (1995). Propriedades de absorção UVA/UVB de produtos naturais. Cosmet Toil (edição em português) 7: 4450 .

Bordignon, J. R., \& Celso, L. et al (2009). Influência do pH da solução extrativa no teor de antocianinas em frutos de morango. Ciência e Tecnologia de Alimentos. Campinas 29(1):183-188.

Bosch, R., Philips, N., Suárez-Pérez, J. A., Juarranz, A., Devmurari, A., Chalensouk-Khaosaat, J., \& González, S. (2015). Mechanisms of Photoaging and Cutaneous Photocarcinogenesis, and Photoprotective Strategies with Phytochemicals. Antioxidants 4(2):248-268. https://doi.org/10.3390/antiox4020248

Busbee, P. B., Busbee, M., Rouse, M., Nagarkatti, M \& Nagarkatti, P. S. (2013). Use of natural AhR ligands as potential therapeutic modalities against inflammatory disorders. Nutrition Reviews 71(6):353-369.

Camouse, M. M., Domingo, D. S., Swain, F. R., Conrad, E. P., Matsui, M. S., Maes, D., Declercq, L., Cooper, K. D., Stevens, S. R., \& Baron, E. D. (2009). Topical application of green and white tea extracts provides protection from solar simulated ultraviolet light in human skin. Experimental Dermatology 18(6):522-526.

Chiari-Andréo, B. G., Almeida, F. B., Yamasaki, P. R., Santos, J. L., Corrêa, M. A, Chin Chung, M. et al (2020). Can natural products improve skin photoprotection? Rodriguésia $71: \mathrm{e} 00672019$.

Choquenet, B., Couteau, C., Paparis, E. \& Coiffard, I. J. (2008). Quercetin and rutin as potential sunscreen agents: Determination of efficacy by an in vitro method. Journal of Natural Products 71(6):1117-1118.

De Paola, M. V. R. V. \& Ribeiro, M. E. (1998). Interação entre filtros solares. Cosmetics \& Toiletries. 10:40-50.

Diffey, B. L., \& Robson, J. (1989). A new substrate to measure sunscreen protection factors throughout the ultraviolet spectrum. Journal of the Society of Cosmetic Chemists 40:127-133.

Epstein, J. H. Biological effect of sunlight. In: Lowe, N. J., Shaath, M. \& Pathak, M. A. Sunscreens: development, evaluation and regulatory aspect. Marcel Dekker, New York. 1990

Ferrari, M., Oliveira, M. S. C., Nakano, A. K., \& Rocha-Filho, P. A. (2008). Determinação do fator de proteção solar (FPS) in vitro e in vivo de emulsões com óleo de andiroba (Carapa guianensis). Revista Brasileira de Farmacognosia. 17:626-630.

Filho, J. M. T. A, Sampaio, P. A., Pereira, E. C. V., de Oliveria Júnior, R. G., Silva, F. S., Almeida, J. R. G. S., Rolim, L. A, Nunes, X. P., \& Araújo, E. C. C. (2016). Flavonoids as photoprotective agents: A systematic review. Journal of Medicinal Plants Research 10(47):848-864.

Flor, J., Davolos, M. R., \& Correa, M. A. (2007). Protetores solares. Química Nova 30(1):153-158.

Giampieri, F., Alvarez-Suarez, J., Tulipani, S., Gonzàles-Paramàs, A. M., Santos-Buelga, C., Bompadre, S., Quiles, J., Mezzetti, B. \& Battino, M. (2012). Photoprotective potential of strawberry (Fragaria $\times$ ananassa) extract against UVA irradiation damage on human fibroblasts. Journal of Agricultural and Food Chemistry 60(9): 2322-2327.

Gould, K. S. (2004). Nature's Swiss Army Knife: The diverse protective roles of anthocyanins in leaves. Journal of Biomedicine and Biotechnology 2004(5): 314-320.

Guaratini, T., Medeiros, M. H. G; \& Colepicolo, P. Antioxidante na manutenção do equilíbrio redox cutâneo: uso e avaliação de sua eficácia. Química Nova 30(1):206-213.

Guaratini, T., Callejon, D. R., Pires, D. C., Lopes, J. N. C., Lima, L. M., Giannella, N. D., Sustovich, C. \& Lopes, N. P. (2009). Fotoprotetores derivados de produtos naturais: perspectivas de mercado e interações entre o setor produtivo e centros de pesquisa. Química Nova 32(3):717-721.

Inal, M. E., Kahramant, A. \& Kkent, T. (2001). Beneficial effects of quercetin on oxidative stress induced by ultraviolet A. Clinical and Experimental Dermatology 26(6): 536-539.

Jallad, K. N. (2016). Chemical characterization of sunscreens composition and its related potential adverse health effects. Journal of Cosmetic Dermatology 16(3):353-357. doi:10.1111/jocd.12282

Jiang, N., Doseff, A. \& Grotewold, E. (2016). Flavones: From Biosynthesis to Health Benefits. Plants 5(2):27. 10.3390/plants5020027

Johncock, W. (2000). Interação de formulações com filtro solar. Cosmetics. \& Toiletries. 12:40-50.

Juzeniene, A. \& Moan, J. (2012). Beneficial effects of UV radiation other than via vitamin D production. Dermato endocrinology 4:109-117. $10.4161 /$ derm. 20013 .

Korkina, L., Kostyuk, V., Potapovich, A., Mayer, W. \& Talib, N., De Luca, C. (2018). Secondary Plant Metabolites for Sun Protective Cosmetics: From PreSelection to Product Formulation. Cosmetics 5(2):32.

Lambert, J. D., Sang, S. \& Yang, C. S (2007). Possible controversy over dietary polyphenols: benefits vs risks. Chemical Research in Toxicology 20(4):583585 . 
Lin, J. Y., Tournas, J. A., Burch, J. A., Monteiro-Riviere, N. A. \& Zielinski, J. (2008). Topical isoflavones provide effective photoprotection to skin. Photodermatology Photoimmunology and Photomedicine 24(2):61-66.

Lívia, P. G. M., Nathália, O. S. G., Mariana, C. M., Andressa, L. S. D., Nayara, L. O. \& Edemilson, C. C. (2018). Extract from byproduct Psidium guajava standardized in ellagic acid: additivation of the in vitro photoprotective efficacy of a cosmetic formulation. Revista Brasileira de Farmacognosia 28(6):692696. https://doi.org/10.1016/j.bjp.2018.08.005

Mota, M. D., Morte, A. N., Silva, L. C \& Chinalia, F. (2020). Sunscreen protection factor enhancement through supplementation with Rambutan (Nephelium lappaceum L) ethanolic extract. Journal of Photochemistry and Photobiology B Biology 205:111837.

Moyal, D. D \& Fourtanier, A. M. (2008). Broad-spectrum sunscreens provide better protection from solar ultraviolet-stimulated radiation and natural sunlightinduced immunosuppression in human beings. Journal of the American Academy of Dermatology 58(5):S149-S154.

Pereira, A. S. Shitsuka, D. M, Parreira, F. J. \& Shitsuka, R. (2008). Metodologia da pesquisa científica. UFSM. https://repositório.ufsm.br/bitstrea m/handle $1 / 1$ 5824/Lic_computacao_metodologia da pesquisa- Cientifica.pdf?sequence=1.

Perugini, P., Simeoni, S., Scalia, S., Genta, I., Modena, T., Conti, B. \& Pavanetto, F. (2002). Effect of nanoparticle encapsulation on the photostability of the sunscreen agent, 2-ethylhexyl-p- methoxycinnamate. International Journal of Pharmaceutics 246(1-2):37-45.

Polonini, H., Brandao, H., Raposo, N., Mouton, L., Yepremian, C., Couté, A. \& Brayner, R. (2014). Ecotoxicological studies of micro- and nanosized barium titanate on aquatic photosynthetic microorganisms. Aquatic toxicology (Amsterdam, Netherlands). 154C:58-70. 10.1016/j.aquatox.2014.05.005.

Ramos, M. F. S., Santos, E. P \& Dellamora-Ortiz, G. M (2010). Avaliação da atividade antissolar e estudos preliminares de fotodegradação da própolis. Revista Fitos, São Paulo 5(3).

Rancan, F., Rosan, S., Boehm, K., Fernandez, E., Hidalgo, M. E., Quihot, W., Rubio, C., Boehm, F., Piazena, H. \& Oltmanns, U. (2002). Protection against UVB irradiation by natural filters extracted from lichens. Journal of Photochemistry and Photobiology B: Biology 68(2-3):133-139.

Ribeiro, C. (2006). Cosmetologia aplicada a dermoestética. Pharmabooks.

Saewan, N. \& Jimtaisong, A. (2013). Photoprotection of natural flavonoids. Journal of Applied Pharmaceutical Science 3(9):129-141.

Saewan, N. \& Jimtaisong, A. (2015). Natural products as photoprotection. Journal of cosmetic dermatology 14(1):1-17.

Sampaio, S. A. P. \& Rivitti, E. A. Dermatologia. (2a ed.), Artes Médicas, 629-42, 839-846, 878-886.

Seok, S. U., Kang, S. Y., Seo, J. W., Kim, S. H., Hwang, K. M. \& Park, E. S. (2016). Formulation of Nanoparticle Containing Everolimus Using Microfluidization and Freeze-Drying. Chemical \& Pharmaceutical Bulletin 64(10):1445-1449. 10.1248/cpb.c16-00049.

Silva, E. E. S., Alencar-Filho, J. M. T., Oliveira, A. P., Guimaraes, A. L., Siqueira-Filho, J. A., Almeida, J. R. G. S. \& Araujo, E. C. C. (2014). Identification of glycosil flavones and determination in vitro of antioxidant and photoprotective activities of Alternanthera brasiliana L. Kuntze. Research Journal of Phytochemistry 8(4):148-154. 10.3923/rjphyto.2014.148.154.

Simis, T. \& Simis, D. (2006). Doenças da pele relacionadas à radiação sola. Revista Faculdade de Ciências Médicas de Sorocaba 8(1):234-242.

Singh, G. \& Kumar, J. Artificial and natural photoprotective compounds. In book: Sunscreens: Source, Formulations, Efficacy and Recommendations. NOVA Science Publishers Inc., USA, 2018: 153-200

Skarupova, D., Vostalova, J. \& Rajnochova Svobodova, A. (2020). Ultraviolet A protective potential of plant extracts and phytochemicals. Biomedical papers of the Medical Faculty of the University Palacký, Olomouc, Czechoslovakia 164(1):1-22.

Survay, N. S., Upadhyaya, C. P., Kumar, B., Young, K. E., Yoon, D. Y. \& Park, S. W. (2011). New genera of flavonols and flavonol derivatives as therapeutic molecules. Journal of the Korean Society for Applied Biological Chemistry 54:1-18.

Tapas, A. R., Sakarkar, D. M. \& Kakde, R. B (2008). Flavonoids as Nutraceuticals: A Review. Tropical Journal of Pharmaceutical Research 7(3):1089-1099.

Toffetti, M. H. F. C. \& De Oliveira, V. R. (2006). A importância do uso do filtro solar na prevenção do fotoenvelhecimento e do câncer de pele. Investigação $6(1)$.

Toyoshima, M., Hosoda, K., Hanamura, M., Okamoto, K., Kobayashi, H. \& Negishi, T. (2004). Alternative methods to evaluate the protective ability of sunscreen against photogenotoxicity. Journal of Photochemistry and Photobiology B: Biology 73(1-2):59-66.

Tsao, R., Yang, R., Young, J. C. \& Zhu, H. (2003). Polyphenolic profiles in eight apple cultivars using high-performance liquid chromatography (HPLC). Journal of Agricultural and Food Chemistry 51(21):6347-6353.

Van Dross, R., Hong, X., Essengue, S., Fischer, S. M. \& Pelling, J. C. (2007). Modulation of UVB-induced and basal cyclooxygenase-2 (COX-2) expression by apigenin in mouse keratinocytes: role of USF transcription factors. Molecular Carcinogenesis 46(4):303-314.

Violante, I. M. P., Souza, I. M., Venturini, C. L., Ramalho, A. F. S., Santos, R. A. N. \& Ferrari, M. (2009). Avaliação in vitro da atividade fotoprotetora de extratos vegetais do cerrado de Mato Grosso. Revista Brasileira de Farmacognosia. 19(2):452-457.

Wolf, R., Wolf, D., Morganti, P. \& Ruocco, V. (2001). Sunscreens. Clinics in Dermatology. 19(4):452-459.

Wei, H., Zhang, X., Wang, Y. \& Lebwohl, M. (2002). Inhibition of ultraviolet light-induced oxidative events in the skin and internal organs of hairless mice by isoflavone genistein. Cancer Letters 185(1):21-29. 
Research, Society and Development, v. 10, n. 5, e0810514603, 2021

(CC BY 4.0) | ISSN 2525-3409 | DOI: http://dx.doi.org/10.33448/rsd-v10i5.14603

Widyarini, S., Husband, A. J. \& Reeve, V. E. (2005). Protective effect of the isoflavonoid equol against hairless mouse skin carcinogenesis induced by UV radiation alone or with a chemical cocarcinogen. Photochemistry and Photobiology 81(1):32-37.

Yoshida, K., Kitahara, S., Ito, D. \& Kondo, T. (2006). Ferric ions involved in the flower color development of the Himalayan blue poppy, Meconopsis grandis. Phytochemistry 67(10):992-998. 